\title{
THE EFFECT OF COMBINING TEACHING GAMES ON ACADEMIC ACHIEVEMENT
}

\author{
Kamilia RADI ${ }^{1}$
}

\section{Istanbul / Türkiye}

p. $718-728$

Received: $22 / 11 / 2021$

Accepted: $10 / 12 / 2021$

Published: 01/01/2022

This article has been scanned I iThenticat No plagiarism detected

\section{Abstract:}

The study deals with the effect of combining games in teaching on the academic achievements in the subject of multiplication in mathematics. The teaching games discussed by the study are: "Social Interaction Assistance" and "Stay in a Movement Learning Activity" of a teaching game, aimed at improving any behavior that is aimed at the purpose of study.

The study involved 50 students from the same grade (third grade) who had once participated in control groups (regular learning) without any use of games) and once in an experimental group (using games in teaching) and then found that the group that experienced learning with the help of teaching games, reached higher and clearer achievements in the field of multiplication compared to the control group. And also, it emerged from the study that there is a significant positive correlation between the variables of teaching games and the improvement in academic achievement.

Key words: Combining Games in Teaching; Academic Achievements; The Subject of Multiplication in Mathematics; "Social Interaction Assistance"; "Stay In A Movement Learning Activity".

http://dx.doi.org/10.47832/2717-8293.15.49 


\section{Introduction}

The prevailing perception is that the game is intended for recreation, leisure and early childhood learning and the game does not find expression during primary school and almost disappears in high school. This perception is a result of concerns that the game is not suitable for learning complex content and may delay the learning power in adulthood, where there is an expectation of formal learning achievement-focused.

Over time, perceptions developed that saw the game in different aspects. For example, in the emotional realm - development of inter-personal communication and empathy that increases inner motivation and enjoyment that contribute to learning (Schiller, 2010) and activation of fine and gross motor skills important for the formation of cognitive connections (Karbach \& Schubert, 2013).

In the cognitive field, the game contributes to the acquisition of knowledge and the creation of new knowledge, to the development of the imagination, creativity and invention, exploration and criticism and acquiring learning habits (Levitt $\&$ Shonkoff, 2010).

This means that the game is an integral part of the learner's natural world and as the use of the game increases for learning purposes learning will be more meaningful and will be accompanied by higher successes and achievements (Morning, 2012).

This work will deal with learning math, in elementary school, through combined game lessons. It is known that many students experience significant difficulties in acquiring and understanding mathematical knowledge, over many years of study. Combining game in mathematics teaching allows for diversity in teaching methods, constitutes an unconventional practice may motivate students to learn mathematics, encourage creativity and make them fun (Reese, 2016).

The aim of the present study is to characterize the integrated learning lessons in heterogeneous primary classes. Therefore the study examines the characteristics of a learning environment that combines play in lessons with reference to motivation, enjoyment, concentrated learning, and a positive identity of the student about himself in heterogeneous classes, and hence the question of research which I discussed in this paper - is there a positive impact of teaching games on academic achievement?

\section{Literature Review}

\subsection{Teaching through games}

Meaningful learning is learning that occurs when it is active (Shute, Rieber \& Van Enk, 2011) because it activates all body systems, senses, cognition and thought, which expands the range of learning options (Boker, 2016).

Many studies dealing with teaching through different types of games point to many benefits: use of games increases learning and makes students take responsibility, encourages collaborations between them and improves the classroom atmosphere. Learning through play is suitable for different types of learners and provides a solution for active learners who have difficulty sitting for a long time. It enables peer non-threatening teaching, improves learning motivation and is a pleasure factor in the class (Boker, 2016). The game serves as a significant tool for strengthening the knowledge and understanding of the material studied (Ben Tzodek and Nachmias, 2011) is a natural way of learning and as such can be harnessed for teaching academic content (Arbel et al., 2011). 


\subsection{The contribution of the game to the development of the individual's personality}

When the individual takes part in an educational game, it allows him to express his personal, latent and visible abilities. The active participant in the educational game usually succeeds in giving expression to his special qualities. Boker (2016) claimed that the game is an integral part of the learner's natural world and as use increases

Boker argued that the game is an integral part of the learner's natural world and as the use in a game for learning purposes increases, learning will be more meaningful and will be accompanied by higher successes and achievements. In addition, the game provides thinking scaffolding for the material being studied (Broza, Ben-David, Kolikant, 2014) and to improve the advantages of the learning game there should be a discussion after the game about strategies in the game, ways of thinking for linking prior knowledge to the new knowledge and to reflect on the various game moves (Broza et al., 2014).

\subsubsection{The contribution of the game to the cognitive field}

In a study by Castellar et al. (2015) they examined whether traditional teaching methods versus teaching through play are different in terms of the impact on different cognitive processes. In their study they combined standard metrics of working memory, viso-motor Skills, accounting gains and self-reporting means of pleasure. It was found that the improvement in account performance as a result of game instruction and traditional instruction is not only different in terms of fun but also in terms of improvements in memory capacity in favor of game teaching.

\subsubsection{The contribution of the game to the social climate in the team}

Tami and Yehieli (2014) claim that there is interaction in the game, and cooperation required from the game, inviting development of moral thinking, out of free will (without the need for "preaching morality"). This means that when the game added value for teamwork exists, and personal responsibility for morality. In this way, it is a natural way to understand and acquire control of social skills (openness, listening, appreciation, conflict management, etc.). The game has long been a factor in the interaction between its participants. The individual goes through, in miniature process of acquiring social skills that will serve him in the future. The more he experiences as a child, the more he will acquire positions and tools that will be available to him and help him as an adult and an individual in the society. Today, more than in previous years, the individual is asked to discover skills of teamwork, work based on interaction, consideration, collaboration, organizational thinking, ability to locate problems and find a solution to them. In the learning game the conditions for success are usually learning, thinking, planning the next step, helping others and understanding

that "enemy" in the game is also "friend" in reality.

\subsection{The game in teaching}

Combining game in studies allows for diversity in teaching methods, constitutes an unconventional practice, may motivate students to learn math, and encourage creativity (when the students themselves build a game) and make them enjoy. It also allows the teacher to be aware of the students' difficulties in the mathematical subject that the game deals with (Reise, 2016). I plan to develop future research to test whether game serves as a factor that encourages learning and reduces anxiety and difficulty in studies.

\subsubsection{The game as one of the aids to overcome the difficulty in teaching mathematics}

According to one of the principles in the psychology of learning, pleasure and enthusiasm help the student to overcome difficulties in studying a particular material. Reese (2016) argues that combining mathematics teaching allows for diversity in methods 
teaching, which is an unconventional practice, may motivate students to learn math, encourage creativity (when students build a game themselves) and make them enjoyable. The game also allows the teacher to face student difficulties with the mathematical subject he deals with. In another study by Vrogte and colleagues (Vrugte, 2015), it was found that the game was able to target students, especially those with low prior knowledge. It is important to draw attention to the fact that children with low prior knowledge are those who have the potential to understand proportional thinking but have not yet encountered the right learning situation to adapt to their potential. Not only that, the study found that students should also have ongoing thinking throughout the game.

\subsection{The relationship between the combining games in teaching and the improvement in achievements}

During the study, the learning activity of social interaction was split into two: "movement interaction" and "verbal interaction" to sharpen the observation in the interaction processes. Both variables were found to be significantly positive correlated with improvement in achievement, but their correlations were relatively low. Keep in mind that the children in the experiment were elementary school students in third grade, and apart from a brief experience in the organizational processes before the beginning of the experiment, were inexperienced in interaction processes. Effective interaction for learning is not self-evident at this age. It is possible that the learning activity "social interaction" should be learned in early processes, so that it is possible to get the most out of it (Reiz, 2016).

Teaching games "Stay in a movement learning activity" include, in fact, a connection of all the behaviors that are done for the benefit of learning. The fact that this essay has received a particularly high correlation indicates that the various learning activities support each other in achieving the goal of improving achievement. Also, the different activities of learning related to game movement provides time for learning to understand the connection of the activities and the meaning of duration.

In a multivariate linear regression analysis, it was found that "stay in the game in teaching" is the most significant predictor of improvement in achievements. Game in such teaching has greater predictive ability than students' "score before" and "estimate". The students' "score before" represents the knowledge with which the learner came to the class. The fact that the learner stayed in the learning activity of game can overcome her basic data, and is significant for most learners, and especially for the weak.

This fact is even more important for the weak who study in heterogeneous classes, where the strong children can help them stay on task and thus promote them considerably. It was showed that when a learner stays in a learning game activity, he can overcome his low starting point, and perhaps even the teacher's prejudices. When taking into account the individual learning activities leaving the "stay in movement learning activity" out of regression, the "before score" and "after score" are revealed as variables that better predict the improvement in learner achievement than separate learning activities. Activities are still found to predict improvement: "Assistance with visual-movement illustration" and "socialmovement interaction". Of particular interest here are the findings concerning the movement interaction. Of the two types of interaction only "movement interaction" was found to be a significant predictor of improvement in achievement. To some extent this finding can be explained by the fact that the children were given during the learning tasks of "interaction movement", accompanied them and was secondary in importance. To understand this explanation one must pay attention to the manner of learning during (Reese, 2016). 


\subsection{Research questions}

In light of the above review, it was hypothesized: There will be a difference in the achievements of students who have studied with the frontal method and in the method of combining game in teaching. Thus it will be found that in the method of teaching combined with game, the achievements of the students be higher than their achievements in traditional frontal teaching.

\section{Methodology}

\subsection{Study population}

The study involved 50 third-graders who learned the subject of multiplication for the first time in the traditional frontal method. The second time they learned to play a game. After each time the students were tested accordingly.

\subsection{Research variables:}

Dependent variable: student achievements.

Independent variable: Combining game in teaching.

Background variables: sex, number of siblings.

\subsection{Instruments:}

A questionnaire consisting of two parts:

Part A - Background data questionnaire including: sex; age; number of siblings at home and student achievements in the first and second exams.

These variables were chosen because they are related to the level of student achievement.

Part B - Questionnaire for testing improvement in the learning process from the combining game. This section includes 8 items for examining combining game in teaching.

\subsection{Research design:}

Research design was divided into two parts: first, a descriptive statistics for information gathering on distribution averages and standard deviations to each of the variables and their factors. Second, for the purpose of testing the hypothesis, a T-test was calculated for dependent samples.

\section{Findings}

\subsection{Description of the study variables}

This study examined the effect of combining game on students' level of achievement, so that 50 students participated in this study. Table 1 shows the distribution of the students' demographic variables.

Table 1: Distribution of the Demographic Variables of the Sample $(n=50)$

\begin{tabular}{|c|c|c|c|}
\hline Variable & Component & Frequency & percentage \\
\hline & Male student & 26 & $52 \%$ \\
\hline Sex & & & $48 \%$ \\
\hline Age & Female student & 24 & $100 \%$ \\
\hline & 8 years & 50 & $12 \%$ \\
\hline Number of siblings in family & No siblings & 6 & $48 \%$ \\
\hline
\end{tabular}




\begin{tabular}{|l|l|l|l|}
\hline & $4-5$ siblings & 20 & $40 \%$ \\
\hline
\end{tabular}

Table 1 shows that 50 students from an elementary school participated in the sample. It appears that all participants are above the age of 8 years (third grade). 'The sample also shows that $52 \%$ of the participants are male students and $48 \%$ are female students. It also shows that $12 \%$ of the participants do not have siblings in the family and another $48 \%$ have 1-3 siblings and the rest $40 \%$ have $4-5$ brothers.

In this study the dependent variable was academic achievement (the two test averages) and the independent variable is learning combined with games.

Table 2: Distribution and scattering indices of learning efficiency and student achievement Frontal method $(\mathrm{n}=50)$

\begin{tabular}{|c|c|c|c|c|c|}
\hline Variable & Average & $\begin{array}{c}\text { Standard } \\
\text { deviation }\end{array}$ & $\begin{array}{c}\text { Minimum } \\
\text { value }\end{array}$ & $\begin{array}{c}\text { Maximum } \\
\text { value }\end{array}$ & scale \\
\hline $\begin{array}{c}\text { Satisfaction with } \\
\text { learning }\end{array}$ & 5.7 & 2.4 & 2 & 9 & $1-10$ \\
\hline $\begin{array}{c}\text { Academic } \\
\text { achievement } \\
\text { (exam average) }\end{array}$ & 72.6 & 11.2 & 40 & 95 & $0-100$ \\
\hline
\end{tabular}

Table 2 shows that the participating students were satisfied at an average level (moderate) $(\mathrm{m}=5.7)$ from the procedure of traditional frontal learning. The standard deviation was high (2.4) which indicates a distribution among the participants in everything related to the degree of students' agreement with the effectiveness of traditional frontal learning in multiplication lesson they learned. Some participants pointed out that indeed the learning efficiency of the frontal method is low (minimum value=2) and there were those who strongly agreed that frontal learning is very effective (maximum value $=9$ )

As for the academic achievements variable it was found that the average achievements of the participating students who studied in the frontal method was $m=82.6$, with a very high standard deviation was found (11.2) and with a lowest score of 40 and a highest score of 95 .

Table 3: Indices of distribution and scattering of learning efficiency and student achievement - combining game in learning $(n=50)$.

\begin{tabular}{|c|c|c|c|c|c|}
\hline Variable & Average & $\begin{array}{c}\text { Standard } \\
\text { deviation }\end{array}$ & $\begin{array}{c}\text { Minimum } \\
\text { value }\end{array}$ & $\begin{array}{c}\text { Maximum } \\
\text { value }\end{array}$ & scale \\
\hline $\begin{array}{c}\text { Satisfaction } \\
\text { with learning }\end{array}$ & 8.3 & 2.7 & 3 & 10 & $1-10$ \\
\hline $\begin{array}{c}\text { Academic } \\
\text { achievement } \\
\text { (exam average) }\end{array}$ & 84.6 & 10.5 & 45 & 100 & $0-100$ \\
\hline
\end{tabular}

Table 3 shows that the participating students were satisfied at an average level $(\mathrm{m}=$ 8.3) of the overall learning process combining game in learning. The standard deviation was high (2.7) which indicates a distribution among the participants in their degree of agreement on the effectiveness of learning combined with game in class. Some participants indicated that indeed the effectiveness of learning combining game is low (minimum value $=3$ ) and there are those who strongly agreed that learning combining game is very effective (Maximum value $=10$ ).

As for the academic achievements variable it was found that the average achievements value of the participating students who studied in the method combining game was $m=84.6$, 
with a very high standard deviation (10.5) and with the lowest score of 45 and the highest of 100.

\subsection{Inferential Statistics}

This study has one hypothesis and it found a difference in satisfaction from the learning process and the students' achievements who studied in the frontal method and in the method of combining game in teaching. Thus it was found that in the teaching method combined with game, satisfaction with the learning process and the students' achievements are higher than satisfaction with the learning process and their achievements in traditional frontal teaching. For the benefit of testing the hypothesis a T-test was calculated for dependent samples.

Table 4: T-test for dependent / paired samples for the satisfaction with the study process variable according to the study method $(n=50)$.

\begin{tabular}{|r|r|r|r|l|l|}
\hline Variable & $\begin{array}{l}\text { Method of } \\
\text { teaching }\end{array}$ & $\mathrm{N}$ & Average & $\begin{array}{l}\text { Standard } \\
\text { deviation }\end{array}$ & $\mathrm{t}$ \\
\hline $\begin{array}{r}\text { Satisfaction with } \\
\text { learning }\end{array}$ & $\begin{array}{r}\text { traditional } \\
\text { Combining } \\
\text { game }\end{array}$ & 50 & 5.7 & 2.4 & \\
\hline
\end{tabular}

Table 4 shows that there is a significant difference in student satisfaction in the two teaching methods $(\mathrm{p}<0.05 ; \mathrm{t}(98)=-1.09)$. In other words, students who studied in the traditional frontal method were found to be moderately satisfied $(\mathrm{sd}=2.4)(\mathrm{m}=5.7)$ which is lower than the average satisfaction of the students who studied in the combing game teaching method $(\mathrm{m}=8.3 ; \mathrm{sd}=2.7)$.

Table 5: T-test for dependent / paired samples for the academic achievements variable according to the study method $(n=50)$.

\begin{tabular}{|r|r|r|r|l|l|}
\hline Variable & $\begin{array}{l}\text { Method of } \\
\text { teaching }\end{array}$ & $\mathrm{N}$ & Average & $\begin{array}{l}\text { Standard } \\
\text { deviation }\end{array}$ & \\
\hline $\begin{array}{r}\text { Academic } \\
\text { achievement }\end{array}$ & traditional & 50 & 72.6 & $11.2^{*}-14.28$ \\
\cline { 2 - 5 } & $\begin{array}{r}\text { Combining } \\
\text { game }\end{array}$ & 50 & 84.6 & 10.5 & \\
\hline
\end{tabular}

$\mathrm{p}<0.05^{*} ; \mathrm{p}<; * * 0.01-\mathrm{p}<{ }^{* * *} 0.001-$

Table 5 shows that there is a significant difference in student achievement in the two teaching methods $(\mathrm{p}<0.05 ; \mathrm{t}(98)=-14.28)$. In other words, students who studied in the traditional frontal method were found to average their achievement $(\mathrm{m}=72.6$; $\mathrm{sd}=11.2)$ which is lower than the grade point average of those students who studied using the teaching integration method $(\mathrm{m}=84.6 ; \mathrm{sd}=10.6)$. In summary, it can be argued that the hypothesis has been fully confirmed.

In addition, variance in student achievements in the context of demographic variables was examined. T-test for non-samples depending on the context of the gender variable according to the teaching method was calculated and a one-way ANOVA to examine the differences in achievements in the variables age and number of siblings in the family in the two methods. Table 6 below shows the distribution for T-test calculations for independent samples.

Table 6: T-test for dependent / paired samples for the academic achievements variable and gender in the traditional study method $(n=50)$. 


\begin{tabular}{|c|c|c|c|c|c|}
\hline Variable & $\begin{array}{c}\text { Method of } \\
\text { teaching }\end{array}$ & $\mathrm{N}$ & Average & $\begin{array}{c}\text { Standard } \\
\text { deviation }\end{array}$ & $\mathrm{t}$ \\
\hline $\begin{array}{c}\text { Academic } \\
\text { achievement }\end{array}$ & Male students & 26 & 72.5 & 11.6 & \multirow{2}{*}{${ }^{*}-5.74$} \\
\cline { 2 - 6 } & Female students & 24 & 72.6 & 11.1 & \\
\hline
\end{tabular}

$\mathrm{p}<0.05^{*} ; \mathrm{p}<$;** $^{*} 0.01-\mathrm{p}<{ }^{* * *} 0.001-$

Looking at Table 6 shows that there are no significant differences between the achievements of the male and female students who studied in the traditional frontal method $(\mathrm{p}=\mathrm{ns} ; \mathrm{t}(50)=-5.74)$, meaning that there is no significant difference in achievements in the context of student gender in the traditional method.

Table 7: T-test for dependent / paired samples for the academic achievements variable and gender in the combining game study method $(n=50)$.

\begin{tabular}{|c|c|c|c|c|c|}
\hline Variable & $\begin{array}{c}\text { Method of } \\
\text { teaching }\end{array}$ & $\mathrm{N}$ & Average & $\begin{array}{c}\text { Standard } \\
\text { deviation }\end{array}$ & $\mathrm{t}$ \\
\hline $\begin{array}{c}\text { Academic } \\
\text { achievement }\end{array}$ & Male students & 26 & 84.3 & 10.64 & \multirow{2}{*}{$*-2.11$} \\
\cline { 2 - 5 } & Female students & 24 & 84.9 & 10.71 & \\
\hline
\end{tabular}

$\mathrm{p}<0.05^{*} ; \mathrm{p}<; * * 0.01-\mathrm{p}<{ }^{* * *} 0.001-$

Looking at Table 7 shows that there are no significant differences between the achievements of the students who studied using the combining game method $(p=n s . t(50)$ $=-2.11$ ), which means that there is no significant difference achievements in the context of student gender in the method of combining game method.

To examine the differences in achievement in the context of age and the number of siblings in the family variables, a one-way ANOVA was calculated.

Table 8 below shows the distribution of ANOVA ( $F$ test) to examine the differences in student achievements in the age context and a number of siblings in the family.

Table 8: One-way ANOVA to the number of siblings in the family variable for academic achievements in both methods $(n=50)$

\begin{tabular}{|c|c|c|c|c|c|}
\hline $\begin{array}{l}\text { Dependant } \\
\text { variable }\end{array}$ & $\begin{array}{l}\text { Number of } \\
\text { siblings }\end{array}$ & $\mathrm{N}$ & Average & $\begin{array}{l}\text { Standard } \\
\text { deviation }\end{array}$ & $\mathrm{F}$ \\
\hline \multicolumn{6}{|c|}{ traditional study method } \\
\hline & No siblings & 6 & 72.5 & 8.7 & \\
\hline \multirow[t]{2}{*}{$\begin{array}{c}\text { Academic } \\
\text { achievement }\end{array}$} & 1-3 siblings & 24 & 72.8 & 11.6 & 21.8 \\
\hline & $4-5$ siblings & 20 & 72.4 & 11.8 & \\
\hline \multicolumn{6}{|c|}{ Combining game method } \\
\hline & No siblings & 6 & 6 & 10.9 & \\
\hline \multirow[t]{2}{*}{$\begin{array}{c}\text { Academic } \\
\text { achievement }\end{array}$} & 1-3 siblings & 24 & 24 & 11.8 & 19.54 \\
\hline & 4-5 siblings & 20 & 20 & 11.4 & \\
\hline
\end{tabular}

Table 8 shows that no significant differences were found in the level of achievements in the context of the number of siblings in the family.

\section{Discussion}

The subject of this study is combining game in teaching and academic achievements. The study focused on examining the relationship between students' achievements for learning combined with game in arithmetic lessons (multiplication). In the study, 50 thirdgrade in elementary school students in the state Arab education participated. The research 
hypothesis was that a difference be found in satisfaction from the learning process and the achievements between students who learned in the frontal method and in the method of combining game in teaching, and that in a teaching method combining game satisfaction with the learning process and students' achievements be higher than in traditional frontal teaching.

For testing the hypothesis a T-test is calculated for dependent / coupled samples. The study findings confirmed the hypothesis and showed that satisfaction with the learning process and achievements of students who learned in the method of combining game were high than the degree of satisfaction and achievements of those students who studied in the traditional frontal method.

The research literature shows that combining with game learning in mathematics helps students in their studies and understanding the learnt material. For example, Reese (2016) argues that combining game in mathematics teaching allows for diversity in teaching methods, which is an unusual practice, that may motivate students to learn math, encourage creativity (when the students themselves build a game) and make them enjoy and also raise their academic achievements. Also game allows the teacher be aware of the students' difficulties in the mathematical subject in which he deals. In her research with third grade students she found that learning through combining game enhanced student achievements. In another study by Vrogte and colleagues (2015) they found that the game was able to target the students, and especially those with low prior knowledge. She found that learning combined with game motivates students to learn and enjoy school.

In my opinion, combining game into learning in classes is important and necessary in order to increase student interest. This is especially strongly expressed at younger ages in primary school so cognitive development improves more when combining learning with game.

In addition, a T-test was calculated for unmatched samples and a one-way ANOVA to examine differences in achievements by gender and the number of siblings in the family in both teaching methods. Findings of t-test and one-way ANOVA showed no significant differences in the level of achievements in the context of gender and the number of siblings in the family.

In conclusion, it was found that learning combined with game positively affects student achievements. These findings provide further evidence for the effects of combining game into learning on student achievements in that they show that environment variable positively affects achievements. In addition, cultivating an environment that encourages creativity as well as thinking strengthens the student's understanding and even increases the interest and thus her achievements increase accordingly.

\section{Summary and Conclusions}

This study examined the effect of combining game in learning on students' achievements in third grade arithmetic.

The findings of the study indicated a difference in the level of satisfaction with learning and achievements in favor of combined with game learning over traditional frontal learning. This study is another study in a large set of studies that examines the issue under investigation and its findings indicate the advantage of combining game into learning for the benefit of studying arithmetic over traditional learning (environment varibable) both at the level of students' satisfaction and at the level of achievements. In addition, no significant 
relationships were found between gender and number of siblings in the student's family on student achievements.

This research has one key conclusion which is that combining game in learning (environment variable) plays an important role in raising student satisfaction and achievements.

As to this research contributions, for example, raising awareness among teachers as well as parents about the benefits of combining game into learning. This situation requires the assimilation of the game as part of the learning process. In addition policy makers in the Ministry of Education have to prepare learning programs based on combining game as part of teaching and learning. I recommend future follow-up research that will include a larger sample of students and include different schools from different ethnic populations. 


\section{Bibliography}

Arbel A., Lachman D. and Epstein V. (2011). Educational Games - Template Kit. Internal Advertising, College Beit Berl Academy.

Hanan, Y. (2011). LAE - Learning in an Adventurous Environment. Eureka Science. Tel Aviv University.

Reese, R. (2016). Course of "Mathematical Games" Oranim College.

Tami, Y. and Yechiel, P. (2014). Game is a study material in disguise - a combination of play in learning. Academic Religious College of Education, Kiryat Shmuel Haifa.

Castellar, E. N., All, A., De Marez, L., \& Van Looy, J. (2015). Cognitive abilities, digital games and arithmetic performance enhancement: A study comparing the effects of a math game and paper exercises. Computers \& Education, 85, 123-133.

Karbach, J \& Schubert,T (2013). Training-induced cognitive and neural plasticity. Frontiers in Human Neuroscience, 7: 6-7.

Ramani, G. B., Siegler, R. S., \& Hitti, A. (2012). Taking it to the classroom: Number board games as a small group learning activity. Journal of Educational Psychology, 104(3), 661.

Schiller, P. (2010). Early brain development research review and update. Brain Development. Schiller, P. (2010). Early brain development research review and update. Brain Development. (pp. 26-30).

Shonkoff, J., and Levitt, P. (2010). Neuroscience and the Future of Early ChildhoodPolicy: Moving from Why to What and How. Neuron 67, 690-691.

Vrugte, J., Jong, T., Wouters, P., Vandercruysse, S., Elen, J., \& Oostendorp, H. (2015). When a game supports prevocational math education but integrated reflection does not. Journal of computer assisted learning, 31(5), 462-480

$\mathrm{Xu}$, A., \& Chen, G. (2016). A study on the effects of teachers' information literacy on information technology integrated instruction and teaching effectiveness. Eurasia Journal of Mathematics, Science \& Technology Education, 12(2), 335346.

Zinn, S., Stilwell, C., \& Hoskins, R. (2016). Information literacy education in the South African classroom: Reflections from teachers' journals in the Western Cape Province. Libri, 66(1), 3144-. 